\title{
Work and Common Mental Disorders in Private Education Teachers: Theoretical Model
}

\author{
Luciana Gisele Brun ${ }^{1}$ \\ Janine Kieling Monteiro ${ }^{1}$ \\ Daniel $\mathrm{Abs}^{2}$
}

\begin{abstract}
The teaching category is among the professions that most fall ill. The objective was to propose a theoretical model that explains the relationship between work context, experiences of pleasure and suffering, and common mental disorders. Data collection was online in a sample of 740 private education teachers from all levels of education in the state of Rio Grande do Sul/Brazil. The cross-sectional and explanatory research used a Self-Reported Questionnaire, the Work Context Assessment Scale and the Scale of Indicators of Pleasure and Suffering at Work as instruments. As a result, the structural equation model presented the variables of work organization, socio-professional relationships, professional achievement, and emotional exhaustion as predictors of common mental disorders. Social-professional relationships, although they present a risk of illness and emotional exhaustion, are at the same time protective and generate professional fulfillment, when evaluated positively. Work organization is an important predictor of emotional exhaustion and mental disorders.
\end{abstract}

Keywords: mental disorders, teachers, mental health

\section{Trabalho e Transtornos Mentais Comuns em Professores do Ensino Privado: Modelo Teórico}

Resumo: A categoria docente está entre as profissões que mais adoecem. Este estudo teve por objetivo propor um modelo teórico que explicasse a relação entre o contexto do trabalho, vivências de prazer e sofrimento e transtornos mentais comuns em docentes. Uma coleta online em uma amostra de 740 professores do ensino privado, de todos os níveis de ensino do Estado do Rio Grande do Sul/Brasil, foi realizada. A pesquisa, transversal e explicativa, utilizou o Self Report Questionnaire, Escala de Avaliação de Contexto de Trabalho e Escala de Indicadores de Prazer e Sofrimento no Trabalho como instrumentos. Como resultado o modelo de equações estruturais apresentou as variáveis organização do trabalho, relações socioprofissionais, realização profissional e esgotamento emocional como preditoras de transtornos mentais comuns. As relações socioprofissionais, embora apresentem risco de adoecimento e esgotamento emocional, também são protetivas e geradoras de realização profissional, quando avaliadas positivamente. A organização do trabalho é preditora de esgotamento emocional e transtornos mentais.

Palavras-chave: distúrbios mentais, professores, saúde mental

\section{Trabajo y Trastornos Mentales Comunes en Docentes de Educación Privada: Modelo Teórico}

\begin{abstract}
Resumen: La categoría docente se encuentra entre las profesiones que más se enferman. El objetivo fue proponer un modelo teórico que explique la relación entre contexto laboral, experiencias de placer y sufrimiento y trastornos mentales comunes en profesores. La recopilación de datos se realizó mediante una muestra de 740 docentes de educación privada de todos los niveles en el estado de Rio Grande do Sul/Brasil. La investigación transversal y explicativa utilizó el Cuestionario de Autoinforme, la Escala de Evaluación del Contexto Laboral y la Escala de Indicadores de Placer y Sufrimiento en el Trabajo como instrumentos. Como resultado, el modelo de ecuaciones estructurales presentó las variables de organización del trabajo, relaciones socioprofesionales, logros profesionales y agotamiento emocional como predictores de trastornos mentales comunes. Las relaciones socioprofesionales presentan un riesgo de enfermedad y agotamiento; además, son protectoras y generan satisfacción profesional, cuando son evaluadas positivamente. La organización del trabajo es predictora de agotamiento emocional y trastornos mentales.
\end{abstract}

Palabras clave: trastornos mentales, profesores, salud mental

\footnotetext{
${ }^{1}$ Universidade do Vale do Rio dos Sinos, São Leopoldo-RS, Brazil

${ }^{2}$ Universidade Federal do Rio Grande do Sul, Porto Alegre-RS, Brazil

Correspondence address: Luciana Gisele Brun. Universidade do Vale do Rio dos Sinos. Avenida Unisinos, 950, Programa de Pós-graduação em Psicologia. Bairro Cristo Rei, São Leopoldo-RS, Brazil. CEP 93.022-750. E-mail: lubrun@gmail.com
}

The changes that have occurred in the world of work since the 1990s, especially because of the technological innovation waves, have caused detrimental effects on the teaching profession, transforming this practice in Brazil, with impacts on teachers' health (Cericato, 2016). Negative effects on the mental health of the professors, such as 
depression, anxiety and burnout, have been pointed out by authors from various countries such as Italy (Borrelli, Benevene, Fiorilli, D'Amelio, \& Pozzi, 2014), Belgium (Van Droogenbroeck \& Spruyt, 2015), Malaysa (Tai, Ng, \& Lim, 2019) and Australia (Corr, Cook, LaMontagne, Waters, \& Davis, 2015).

In general, research studies show that the teaching work has always had peculiar characteristics, such as intense intellectual load and emotional involvement, but special attention has been given to the negative effects on teachers' mental health (Abreu, Coelho, \& Ribeiro, 2016; Amaro \& Dumith, 2018; Assunção, 2019; Baptista, Soares, Raad, \& Santos, 2019). The point is that the content of the teachers' work is not restricted to the classroom but includes other activities, such as: relationships with the community and school management, participation in the planning of the pedagogical project, curricular reformulations that change the teaching plans and methods, participation in councils, guidance, scientific production and publication, area groups, and the standardized evaluation of students' and teachers' performance. These changes express an expansion of the social functions and roles, requiring the exercise of new competences, in addition to increasing the teachers' workload (Assunção \& Abreu, 2019).

The efforts necessary to adapt to these changes, including increased demands and workload, conflicting interpersonal relationships, and unfavorable conditions in the school environment, have been identified as the main reasons for mental health problems among teachers (Cortez, Souza, Amaral, \& Silva, 2017; Luz, Pessa, Luz, \& Schenatto, 2019; Marchetti, Busnello, \& Kolhs, 2016). To understand how the teaching work context presents itself nowadays, the Psychodynamic of Work (PDW) theory was used, which focuses on three dimensions: socio-professional relations, work organization, and working conditions (Dejours, 1992). Although the French PDW is focused on the study of suffering normality, recent Brazilian research studies from this perspective (Monteiro, Moraes, Mendes, \& Merlo, 2017) have indicated its powerful use for understanding the factors that contribute to psychological distress and can culminate in mental illness. This is mainly due to the difficulty in mobilizing a labor collective.

Work organization involves certain management style of the educational institution and, at the same time, provides physical and human conditions for the professors to deal with the obstacles of the real condition of work (Dario \& Lourenço, 2018). Examples are the prescriptions of the objectives and strategies to achieve the expected results in the classroom; the real participation in decision-making that affect teaching; the value and recognition given to what is done; and the form, clarity and quality with which formal and informal communication with the professor is carried out (Mariz \& Nunes, 2013).

In its turn, the working conditions are related to social support, as well as to the physical and material structure for problem resolution. It also includes access to information about the responsibilities and limits of the performance, the opportunity for career development, the facilities and equipment available, the commute to the workplace, the interface between work and home, the double/triple workday, the remuneration, and the organization of the schedules (Borrelli et al., 2014).

The socio-professional relationships that make up the work context are permeated by the professor's perception about the quality of the relationships with hierarchical superiors and with other people in the workplace (colleagues, institution employees), characterized, or not, by mutual acceptance, the presence of open dialog, cooperation, professional recognition, or isolation and competition (Dejours, 1992). This is the understanding used in this study, given that a more current concept, proposed by Dejours (2014), is derived from this initial concept and the instruments available for use in this study are also based on this older conceptualization.

Another construct used in this study, experiences of pleasure and suffering, addresses that the context of the teaching work imposes the intense use of social and intellectual competences that end up mobilizing great psychological energy for their realization. The management of this psychological burden mobilizes positive and negative emotions and leads to the meaning of these experiences. It is produced from the teachers' own life story and moral values, but it takes on peculiar meanings coming from the work context in which they are inserted at that moment. In this sense, the permanence of the experience of suffering for long periods indicates the failure in the use of the defense or coping strategies. This situation is considered as the main cause of illness (Baptista, Soares, Raad, \& Santos, 2019).

This illness can be prevented before it turns into an installed disease, through the early identification of the symptoms of distress and of Common Mental Disorders (CMDs). Common mental disorders, also called minor mental disorders, or even minor psychiatric disorders (MPDs), are neurotic symptoms such as insomnia, irritability, fatigue, somatic symptoms, forgetfulness and difficulty concentrating. The identification of the CMDs by itself not only allows producing a mental ailment diagnosis; it also contributes to signaling a warning about illness risk factors, including subjects already ill among them (K.O.B. Santos, Araújo, \& Oliveira, 2009).

There is a limited number of research studies relating CMDs and professors. However, those that address the theme report high CMD rates in the professional category. Studies conducted in the metropolitan region of Recife/ Pernambuco and in Belo Horizonte/Minas Gerais showed CMD prevalence values of $37.1 \%$ and $50.3 \%$, respectively, in samples of professors working in the municipal public education network (Lima, Coêlho, \& Ceballos, 2017).

In private education, a study with teachers from a Higher Education Institution in Minas Gerais/Brazil was identified. The research showed a CMD prevalence value of $19.5 \%$ among 175 professors (Ferreira et al., 2015). Another study aimed at verifying the prevalence and the factors associated to the CMDs in private education teachers from Rio Grande do Sul/Brazil, in a sample of 740 professors working in 
different education levels. The research evidenced a CMD prevalence value of $55 \%$, a percentage considered high and alarming (Monteiro, Brun, Santos, Tundis, \& Cardon, 2019).

Consequently, the objective of this study was to propose a theoretical model that explained the relationship between the work context, pleasant experiences and of distress, and common mental disorders in teachers. For this purpose, the work context (the conditions, socio-professional relations, and work organization), the experiences of pleasure and suffering (professional exhaustion, freedom of expression, professional fulfillment, lack of recognition), and the occurrence of Common Mental Disorders in private education professors in the state of Rio Grande do Sul were related. Its working hypothesis was the existence of a mediating relationship of the experiences of pleasure and suffering on the occurrence of Common Mental Disorders from the professors' work context.

\section{Method}

The study originated from a larger project developed by a research group from LaborClínica (Laboratório de Clínica do Trabalho) of Universidade do Vale do Rio dos Sinos (Unisinos). It has a quantitative and cross-sectional design, of an explanatory nature (Creswell, 2007).

\section{Participants}

The total population of teachers with active labor contracts, that is, working in private education in the state of Rio Grande do Sul/Brazil, was around 28,602 according to the records of SINPRO-RS/Sindicato dos Professores do Ensino Privado do Rio Grande do Sul (Union of Private Education Professors in Rio Grande do Sul). These teachers include those unionized and non-unionized, of all genders, over the age of 18 , distributed among the following schooling levels: Kindergarten, Elementary School, High School, and Higher Education.

The sample was composed of 740 teachers, $70 \%$ women $(n=518)$ and $30 \%$ men $(n=221)$, who worked in private teaching institutions, located in different cities and regions in the state of Rio Grande do Sul, Brazil, considered sufficient since the minimum and representative estimate was 381 answers, with an error rate of 5\% and a confidence index of $95 \%$ (G. E. O. Santos, 2018). The minimum estimate for performing structural equation modeling is 200 subjects, as indicated by Byrne (2001), so the sample used can also be considered adequate for performing the analysis.

The age of the sample varied between 18 and 72 years old, with a mean of $43.46(S D=11.08)$; most of them, $66.4 \%$, is married or lives in a stable union $(n=491)$ and $60.4 \%$ has children $(n=447)$. The professors were active in the profession for a period that varied from one to 52 years, with a mean of 15.29 years $(S D=10.33)$ and have worked in the current Teaching Institution for a mean of 10.42 years $(S D=8.75)$. Thirty percent $(n=222)$ of the professors worked in more than one teaching institution and $33 \%(n=241)$ had another paid activity in addition to teaching. The mean class size was $30.89(S D=24.60)$ with 500 being the maximum number of students in a single class (Distance Learning). The teaching level at which teachers worked the most hours was higher education, $60 \%(n=451)$, followed by elementary school with $18 \%(n=133)$, high school with $13 \%(n=98)$ and kindergarten with $7.7 \%(n=57)$.

The salaries of the professors in the sample, in ascending order, were up to one minimum wage (R $\$ 1,276)$ for $4.5 \%(n=33)$, between one and three wages ( R \$ $1,277-\mathrm{R} \$ 3,828)$ for $27 \%(n=189)$, between three and five wages $(\mathrm{R} \$ 3,829-\mathrm{R} \$ 6,380)$ for $25.3 \%(n=187)$, between five and eight wages ( $\mathrm{R} \$ 6,381-\mathrm{R} \$ 10,208)$ for $26 \%(n=193)$, between eight and 11 wages $(\mathrm{R} \$ 10,209-\mathrm{R} \$ 14,036)$ for $12 \%(n=89)$ and more than 11 wages $(\mathrm{R} \$ 14,037)$ for $5 \%(n=36)$. Most of the professors surveyed, $37 \%$, had completed some master's degree $(n=273)$, followed by $26.6 \%$ with some $\mathrm{PhD}(n=197)$; specialization, $20 \%(n=146)$; graduate degree, $15 \%(n=115)$; and high school/technical degree, $0.4 \%(n=3)$.

Regarding the health conditions of the professors who made up the sample studied, $35 \%$ had some chronic disease $(n=258)$ and $9 \%(n=66)$ were away from work for more than 15 days in the previous year (2015). The professors who sought psychological or psychiatric appointments in the previous year (2015) accounted for $37 \%(n=272)$.

\section{Instruments}

Sociodemographic and work questionnaire. It sought to characterize the sample and to survey specific variables of the work context and the professor's health, such as: age, schooling, gender, time at work, time at the institution, workload, number of students served, whether they have health problems, whether they take any medication, etc.

Self-Reporting Questionnaire (SRQ-20). Validated in Brazil by Mari and Williams (1986) and widely used in research studies, it is employed to screen Common Mental Disorders (CMDs) through the identification of nonpsychotic symptoms such as insomnia, fatigue, irritability, forgetfulness, difficulty concentrating and somatic complaints (Mari \& Williams, 1986). It consists of 20 questions, which encompass four groups of symptoms: (1) depressive-anxious mood, (2) depressive thoughts, (3) somatic symptoms, and (4) decreased vital energy (K.O.B. Santos et al., 2009). The answers are dichotomous (yes/no). The scores obtained are related to the probability of presenting non-psychotic disorders, varying from 0 (no probability) to 20 (extreme probability) (Gonçalves, Stein, \& Kapczinski, 2008). The cutoff point used was 7, both for men and for women. The cutoff point chosen for this analysis presented $83 \%$ sensitivity and $80 \%$ specificity, in the validation study conducted by Mari and Williams (1986). In the study by Gonçalves et al. (2008), a Cronbach's alpha value of 0.86 was obtained, similar to that obtained in this study $(\alpha=0.88)$.

Work Context Assessment Scale (Escala de Avaliação do Contexto do Trabalho, EACT). Developed and validated 
in Brazil by Mendes and Ferreira (2007), it analyzes three factors: work organization (11 questions with a Cronbach's alpha of 0.88 , in our study), socio-professional relationships (10 items with an alpha of 0.02) and working conditions (10 items with an alpha of 0.93 ). Its analysis must be performed by factor, and its result can be classified in three different levels: (1) most negative, severe evaluation ( $>3.70$ ); (2) most moderate, critical evaluation (between 2.30 and 3.69); (3) most positive, satisfactory evaluation $(<2.29)$. The data from Mendes and Ferreira (2007) point to a structure with a total variance of $38.46 \%$, KMO of 0.93 , and correlations above 0.25 . The scale is of the Likert type composed of five points ranging from 1 to $5(1=$ never, $2=$ rarely, $3=$ sometimes, $4=$ frequently, and $5=$ always) (Mendes \& Ferreira, 2007).

Scale of Indicators of Pleasure and Suffering at Work (Escala de Indicadores de Prazer e Sofrimento no Trabalho, EIPST). Developed and validated in Brazil by Mendes and Ferreira (2007), it is composed of four factors: two to evaluate pleasure - professional fulfillment ( 9 items with an alpha of 0.93 in this study) and freedom of expression (8 items with an alpha of 0.87 ) - and two to analyze suffering at work: lack of recognition (8 items with an alpha of 0.90$)$ and emotional exhaustion (7 items with an alpha of 0.91 ). It is a 7-point (0 to 6) Likert-type scale that assesses the occurrence of the experiences of the indicators (from $0=$ not once, $1=$ once, to $6=$ six or more times). Its objective is to evaluate, in the past six months, the occurrence of experiences of indicators of pleasure and suffering. For the pleasure factors, the items are positive; the analysis must be done per factor and classified into three levels: (1) most positive/satisfactory evaluation $(>4.00)$; (2) moderate/critical evaluation (between 3.90 and 2.10); (3) severe evaluation $(<2.00)$. For the suffering factors, considering that the items are negative, the analysis must be done per factor and classified on three levels: (1) most negative, severe evaluation (> 4.00); (2) moderate, critical evaluation (between 3.90 and 2.10); (3) least negative, satisfactory evaluation $(<2.00)$.

\section{Procedure}

Data collection. Data collection took place exclusively via the Internet (online). To proceed with the initial collection, the professors were contacted by the union through the professors' registration file, which included both unionized and non-unionized teachers. The e-mail message contained a brief presentation, general objectives and a link to answer the questionnaire, which was elaborated with Google Forms. It was estimated that filling out the Form would take around fifteen minutes, and it could be done using any device with an Internet connection.

Collection was conducted at the end of the 2015 school term, from October to December, and from March to May 2016, by sending an email message from the union. After 20 days, a second invitation message was sent, identical to the first. One month after the first message, the snowball method was applied to find new respondents. In addition to that, the research was publicized in the Union's website. Finally, it was also publicized in the social media.

Data analysis. The data of the questionnaire were organized and analyzed by using the Statistical Package for Social Science for Windows (SPSS) and the AMOS software, version 22.0. Structural Equation Modeling with Maximum Likelihood estimates was performed as a data analysis strategy to verify if the theoretical relationships between the investigated concepts have construct validity. This is a multivariate analysis and is characterized by composing regression analyses with factor analysis (Hair, Black, Babin, Anderson, \& Tatham, 2009), of a deductive nature, since the elaboration of the models mainly follows the theoretical fundamentals (Byrne, 2001).

Structural equation analysis consists of building a model of causal relationships between observed variables and latent variables, which results in a variance-covariance matrix (Blunch, 2012). It results in indicators having different sensitivity proposals and which are called fit indexes, the best-known ones being $\mathrm{x}^{2}$ (chi-square) and the Comparative Fit Index (CFI), which were used in this study.

\section{Ethical Considerations}

This study observed the norms set forth in Resolution No. 466/2012 of the Ethics and Research National Commission, being approved by the Ethics Committee of Universidade do Vale do Rio dos Sinos/Unisinos (Project No. CEP 15/079, project version: 06/12/2015, FICF version: 06/12/2015, Certificate of Presentation for Ethical Appreciation (Certificado de Apresentação de Apreciação Ética, CAAE) number 45706115.5.0000.5344.

\section{Results and Discussion}

The conditions of homogeneity and normality of the variables in the sample were observed for violations of the assumptions of the analyses. ANOVA tests were also conducted to verify the homogeneity of the sample for common mental disorders (CMDs) and no significant differences were found for the outcome variable in relation to gender, teaching level, and schooling. Subsequently, the data were analyzed with the Structural Equation Modeling technique, Maximum Likelihood method, to verify the structure of relationships between work context (EACT), pleasure and suffering (EIPST) and the occurrence of common mental disorders (CMDs). Two models were tested: the first with the dimensions arranged as initially proposed for the model, and the second with the dimensions that showed significant relationships and therefore remained in the model. Initially, a first model was established with the dimensions of the scales, identified as latent variables in the analysis, as shown in Figure 1. In the initial model, the latent 
variables of the instruments that would theoretically propose causality relationships were associated. Namely: the three factors of the EACT (working conditions - Work Cond, socio-professional relations -Soc Prof Rel, and work organization -Work Org) and the four factors of the EIPST (freedom of expression - Freed, professional fulfillment - Prof Ful, lack of recognition - Recog, and emotional exhaustion - Em Ex), in addition to the overall results for the SRQ-20 with the cutoff point in 7 affirmative statements for the presence of CMDs.

The data entered into the initial model (Figure 1) showed some violations of multivariate normality. As indicated by Coenders Gallart, Batista-Foguet and Saris (2005) this occurrence is compensated for by using the Bootstrap strategy for estimating the values, which was done in this case. In the first model generated, some relationships were not significant and, for this reason, were removed from the final model. Namely: Working Conditions, Freedom of Expression, and Lack of Recognition.

The relationships between all the variables introduced in the analysis which generated the two models and the respective fit indexes are presented in Table 1 . It can be verified that the fit indexes indicated that the final model is adequate to understand the occurrence of Common Mental Disorders in the sample of professors working in the private education network.

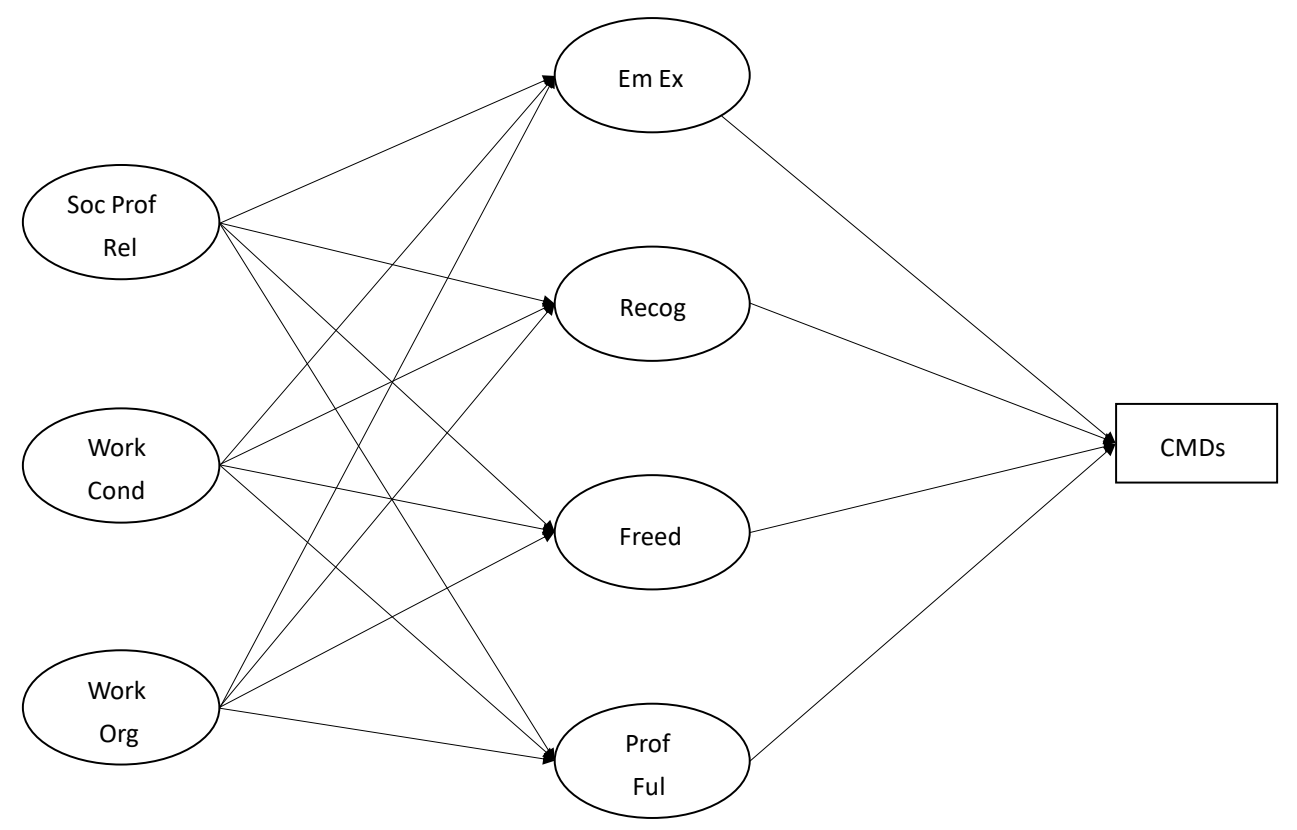

Figure 1. Initial structural equation model with latent variables only.

Key. Soc Prof Rel = Socio-Professional Relations; Work Cond = Working Conditions; Work Org = Work Organization; Em Ex = Emotional Exhaustion; Recog = Recognition; Freed = Freedom; Prof Ful = Professional Fulfillment; CMDs = Common Mental Disorders.

Table 1

Fit Indexes of the Models of Structural Equations

\begin{tabular}{ccccccc}
\hline Model & $\mathbf{x}^{\mathbf{2}}$ & DoF & Sig. & NFI & CFI & RMSEA (90\% CI) \\
\hline Initial & $5,710.18$ & 1,891 & $\mathrm{p}>0.001$ & 0.870 & 0.909 & $0.052(0.051-0.054)$ \\
Final & $2,218.38$ & 634 & $\mathrm{p}>0.001$ & 0.906 & 0.931 & $0.058(0.056-0.061)$ \\
\hline
\end{tabular}

Note. $\mathrm{X}^{2}=$ Chi-square; $\mathrm{DoF}=$ Degrees of Freedom; Sig. = Significance; NFI = Normed Fit Index; CFI = Comparative Fit Index; RMSEA $=$ Root Mean Square Error of Approximation.

The weights found indicate prediction of the Socioprofessional Relationships for Emotional Exhaustion $(\beta=0.186)$ and, conversely or negatively, of the Socioprofessional Relationships for Professional Fulfillment $(\beta=-0.630)$. Work Organization is a predictor of Emotional Exhaustion $(\beta=0.563)$ and Emotional Exhaustion has a significant causal relationship with increased CMDs $(\beta=0.527)$. Professional Fulfillment is inversely, or negatively, associated with Common Mental Disorders $(\beta=-0.333)$.

Figure 2 presents the Final Model of structural equation. In this, the variables whose relationship was considered significant were kept. The index of 0.931 for CFI is considered acceptable, since the number of variables involved in the model is high. 


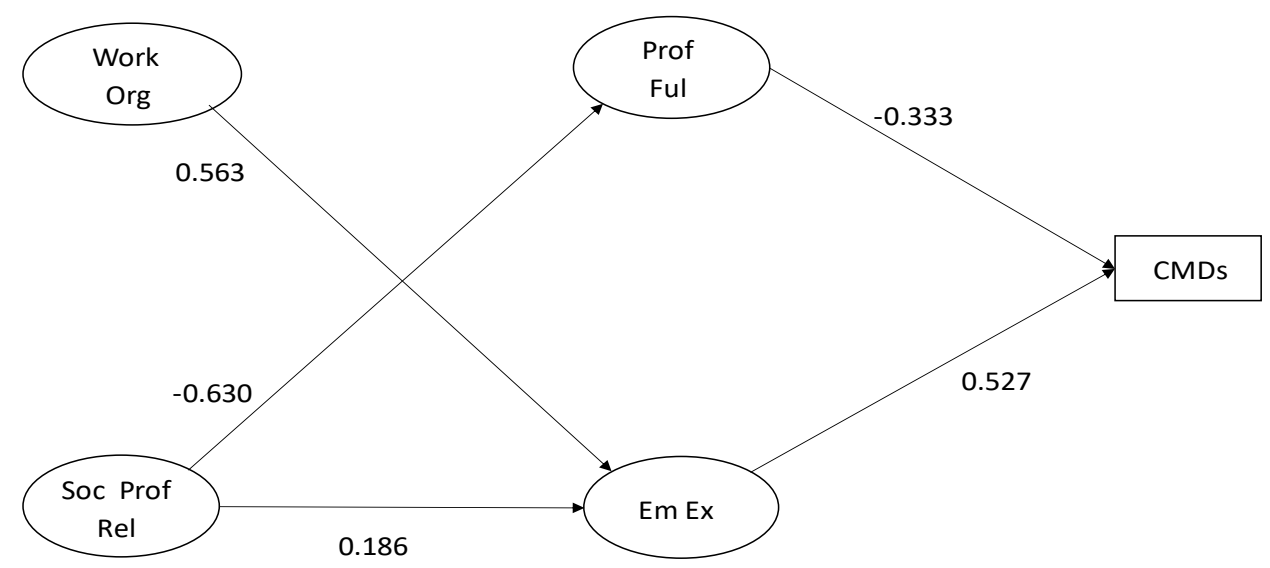

Figure 2. Final model of structural equation with standardized weights (simplified).

Key. Soc Prof Rel $=$ Socio-Professional Relations, Work Org = Work Organization, Em Ex = Emotional Exhaustion, Prof Ful $=$ Professional Fulfillment, $\mathrm{CMDs}=$ Common Mental Disorders.

In Figure 2, it can be seen that the socio-professional relationships can be predictors of both emotional exhaustion and professional fulfillment, indicating the ambiguity and importance of this dimension in teaching. Socio-professional relations are dynamic and fluctuate according to the context, the people, and the needs that are constantly being updated. The socio-professional relationships can be separated in two groups: (1) with superiors and (2) with colleagues.

The professors consider the relationships with their superiors unsatisfactory when the tasks are not clearly defined ( $\beta=0.601)$; autonomy is non-existent $(\beta=0.679)$; distribution of tasks is unfair $(\beta=0.724)$; the employees are excluded from the decisions $(\beta=0.733)$; there are difficulties in communication between bosses and subordinates $(\beta=0.827)$; there is lack of support from the bosses for their professional development $(\beta=0.834)$; and the information they need to perform their work is difficult to access $(\beta=0.682)$. From these results, it can be concluded that the relationship with superiors, which is permeated by the constant updates in the way of managing and teaching in recent years, are the cause of suffering, confirming the studies by Brasil et al. (2016) and Neves and Silva (2006).

Unsatisfactory socio-professional relationships with colleagues, on the other hand, contribute to emotional exhaustion when there are: professional disputes in the workplace $(\beta=0.654)$; lack of integration in the work environment $(\beta=0.753)$; and communication between employees is unsatisfactory $(\beta=0.724)$. This indicates more competition and less cooperation, factors that contribute to the increase of illness in the group under study.

Brasil et al. (2016) and Neves and Silva (2006) also indicate that the socio-professional relationships cause suffering to the professors in their relationships with the students, when there is difficulty in operating class-control, lack of social recognition, and disqualification. Conflicts arise from the perceptions of student failure and error that fall on the professor's management. On the other hand, the affective dimension of these relationships is a source of professional fulfillment $(\beta=-0,630)$ (Neves \& Silva, 2006). In Belgium, a study was conducted to assess the professors' perception of their professional relationships, and the results revealed the association between teachers' wellbeing and the relationships between professors and students. On the other hand, it was associated with burnout (Van Droogenbroeck \& Spruyt, 2015).

In summary, the analysis points out the complexity of these work relationships and explains that the socioprofessional relationships are configured both as protective and risk factors for the intensification of CMDs. Thus, when they promote emotional exhaustion, they also contribute to illness, setting them up as predictors for CMDs.

In this paper, work organization (WO) was strongly associated with emotional exhaustion $(\beta=0.563)$, which is characterized by perceived stress, frustration, insecurity, weariness, and feelings of worthlessness. The WO evaluated by the scale used refers to the content of the tasks, pace of work, norms and control, factors highlighted as problematic in current teaching, since, in addition to the mental load, new skills (such as technological ones) are determined, increasing the work demand and overload and with decreased autonomy (Assunção \& Abreu, 2019).

In this case, we are faced with emotional exhaustion, which was the risk factor that was most strongly related to the increase in CMDs $(\beta=0.527)$, so it is the work aspect that most deserves attention from the professors and managers of teaching institutions. The CMDs are correlated with burnout (Medeiros-Costa, Maciel, \& Fernandes Gurgel, 2018).

National and international studies associate depression, stress and burnout in professors with the current characteristics of the work context. Stressful events and lack of work support are among the most interfering factors (Arias Gallegos, Huamani Cahua, \& Ceballos Canaza, 2019; Baptista, Soares, Raad, \& Santos, 2019; Brasil et al., 2016; Brito Laredo, 2018; Villaverde, Unda, Escotto, \& Flores, 2019). 
At this point, the management of private teaching institutions has met the "productive limit" of their professionals. In other words, when management forms focus on cost reduction, they overload the ability to maintain the balance of the teacher's mental health and promote the emergence of CMDs (Monteiro et al., 2019). Without the necessary balance to maintain their health, sick professors can no longer work, and the institution can no longer exploit the surplus value. Here, by intensifying the pace of work, there is more productivity for the same salary, generating profit. The counterpoint of this mercantilist management priority is that from then on people are faced with unproductivity, since teachers' emotional exhaustion prevents live work, which is indispensable to the organization (Dejours, 2014). A reference to the concept that explains that work which has value and usefulness for the satisfaction of human needs, physical and intellectual. It has value and usefulness for the professors themselves, as well as for the one for whom they work (Freitas, 2013).

One way to invest in the professors' health, proposed by the PDW, focuses on valuing cooperation by the management of the teaching institutions. In this sense, it needs to be encouraged, but not imposed. It occurs in socializing moments, spontaneously among people. Recognition, mutual support, and spaces/time where dialog is promoted are practices that can be used. Dialog with the professors must be maintained and instigated by their superiors who need to provide an environment of trust and openness for negotiation. Other proposals come from the activity clinic, which also proposes interventions by building cooperation and resorting to qualified listening (Barros, Brito, \& Clemente, 2018; Conceição, 2019).

A relevant implication of this work in the interventions with the population refers to the necessary investment of the school organizations in the promotion of teachers' mental health care (Dalcin \& Carlotto, 2018), directed towards positive socio-professional relationships, as indicated by the theoretical model tested, this being the dimension that showed significant relationships and of greater weight in the experiences of pleasure and suffering, and indirectly in the occurrence of CMDs. Given these results, a suggestion for a powerful intervention, according to the PDW, would be the cooperation clinic. This has as its proposal the sharing of experiences about work situations, especially the difficult ones, seeking a strengthening of the collective and micro-transformations of work. This sharing can assist in increasing trust and collaboration in the group, through the "exchange of affections and intelligences toward the creation of new ways of being" (Oliveira \& Ferreira, 2015, p. 171). In the professors, strengthening cooperation can mitigate work exhaustion.

As an effect, it is also suggested to create and supervise public policies for the promotion and prevention of teachers' mental health, as effective as those that seek to regulate the management of the teaching institutions, offering the necessary support for quality education.
Finally, the theoretical model presented does not encapsulate or circumscribe all the variables that impact on the CMDs in professors, and more relational variables need to be included, as well as the development of a new culture of teacher appreciation in the national context. It is suggested, then, that new research studies should also address the public sector and seek to integrate the variables herein studied.

\section{References}

Abreu,M.A.G.M.,Coelho,M.T.A.D.,\&Ribeiro,J.L.L.S.(2016). Percepção de professores universitários sobre as repercussões do seu trabalho na própria saúde [University professors' perception of the repercussions of their work on their own health]. Revista Brasileira de Pós-Graduação, 13(31), 465-486. doi:10.21713/2358-2332.2016.v13.1155

Amaro, J. M. R. S., \& Dumith, S. C. (2018). Sonolência diurna excessiva e qualidade de vida relacionada à saúde dos professores universitários [Excessive daytime sleepiness and quality of life related to the health of university professor]. Jornal Brasileiro de Psiquiatria, 67(2), 94-100. doi:10.1590/00472085000000191

Arias Gallegos, W. L., Huamani Cahua, J. C., \& Ceballos Canaza, K. D. (2019). Burnout syndrome in school teachers and university professors: A psychometrical and comparative analysis from Arequipa City. Journal of Educational Psychology: Propósitos y Representaciones, 7(3), 72-91. doi:10.20511/pyr2019. v7n3.390

Assunção, A. A. (2019). Saúde dos professores da Educação Básica no Brasil [Schoolteachers' health in Brazil]. Cadernos de Saúde Pública, 35(Suppl. 1), e00002619. doi:10.1590/0102-311x00002619

Assunção, A. A., \& Abreu, M. N. S. (2019). Pressão laboral, saúde e condições de trabalho dos professores da Educação Básica no Brasil [Pressure to work, health status, and work conditions of schoolteachers in Basic Education in Brazil]. Cadernos de Saúde Pública, 35(Suppl. 1), e00169517. doi:10.1590/0102311x00169517

Baptista, N. M., Soares, T. F. P., Raad, A. J., \& Santos, L. M. (2019). Burnout, estresse, depressão e suporte laboral em professores universitários [Burnout, stress, depression and job support in university professors]. Revista Psicologia: Organizações e Trabalho, 19(1), 564-570. doi:10.17652/rpot/2019.1.15417 
Barros, M. E. B., Brito, J. M., \& Clemente, O. P. (2018). Narrativas da docência: Dimensão sensível do trabalho de professores e pesquisadores [Teaching narratives: Sensitive dimension of the work of teachers and researchers]. Fractal: Revista de Psicologia, 30(1), 3038. doi:10.22409/1984-0292/v30i1/1479

Blunch, N. J. (2012). Introduction to structural equation modeling using IBM SPSS statistics and AMOS. London, United Kingdom: Sage.

Borrelli, I., Benevene, P., Fiorilli, C., D’Amelio, F., \& Pozzi, G. (2014). Working conditions and mental health in teachers: A preliminary study. Occupational Medicine (Oxford), 64(7), 530-532. doi:10.1093/ occmed/kqu108

Brasil, C. C. P., Batista, M. H., Melo, A. K. S., Ibiapina, F. L. P., Brilhante, A. V. M., \& Silva, R. M. (2016). The context of teaching and its influence on psychic suffering of primary education teachers. Revista Brasileira em Promoção da Saúde, 29(2), 180-188. doi:10.5020/18061230.2016.p180

Brito Laredo, J. (2018). Calidad educativa en las instituciones de educación superior: Evaluación del síndrome de burnout en los profesores [Educational quality in higher education institutions: Assessment of burnout syndrome in teachers]. Revista Iberoamericana para la Investigación y el Desarrollo Educativo, 8(16), 516-534. doi:10.23913/ride.v8i16.356

Byrne, B. M. (2001). Structural equation modeling with AMOS: Basic concepts, applications, and programming. Mahwah, NJ: Lawrence Erlbaum.

Cericato, I. L. (2016). A profissão docente em análise no Brasil: Uma revisão bibliográfica [The teaching profession under analysis in Brazil: A literature review] Revista Brasileira de Estudos Pedagógicos, 97(246), 273-289. doi:10.1590/S2176-6681/373714647

CoendersGallart,G.,Batista-Foguet,J.M.,\&Saris,W.E.(2005). Temas avanzados en modelos de ecuaciones estructurales. Madrid, España: Muralla.

Conceição, K. C. S. S. (2019). Professores em formação no âmbito do Pibid-Capes: Uma abordagem do planejamento e realização de aulas por meio da clínica da atividade [Student teachers in the scope of PibidCapes: An approach to class planning and teaching practice through the clinic of activity]. Revista Brasileira de Linguística Aplicada, 19(1), 29-47. doi:10.1590/1984-6398201812653

Corr, L., Cook, K., LaMontagne, A. D., Waters, E., \& Davis, E. (2015). Associations between Australian early childhood educators' mental health and working conditions: A crosssectional study. Australasian Journal of Early Childhood, 40(3), 69-78. doi:10.1177/183693911504000310
Cortez, P. A., Souza, M. V. R., Amaral, L. O., \& Silva, L. C. A. (2017). A saúde docente no trabalho: Apontamentos a partir da literatura recente [Teachers health in the workplace: Evidence from recent literature]. Cadernos Saúde Coletiva, 25(1), 113-122. doi:10.1590/1414$462 \times 201700010001$

Creswell, J. W. (2007). Projetos de Pesquisa: Métodos qualitativo, quantitativo e misto [Research Projects qualitative, quantitative and mixed methods] (M. F. Lopes, Trans., 2nd ed.). Porto Alegre, RS: Artmed.

Dalcin, L., \& Carlotto, M. S. (2018). Avaliação de efeito de uma intervenção para a Síndrome de Burnout em professores [Evaluation of the effect of an intervention for Burnout Syndrome in teachers]. Psicologia Escolar e Educacional, 22(1), 141-150. doi:10.1590/217535392018013718

Dario, C. V., \& Lourenço, M. L. (2018). Cultura organizacional e vivências de prazer e sofrimento no trabalho: Um estudo com professores de Instituições Federais de Ensino Superior [Organizational culture and experiences of pleasure and suffering at work: A study with teachers from Federal Institutions of Higher Education.]. Organizações em Contexto, 14(27), 345395. doi:10.15603/1982-8756/roc.v14n27p345-395

Dejours, C. (2014). A avaliação do trabalho submetida à prova do real - Crítica aos fundamentos da avaliação. [The evaluation of the work submitted to the proof of reality - Criticism of the fundamentals of the evaluation.]. $2^{\mathrm{a}}$ reimpressão. In: Sznelwar, L. I.; Mascia, F. L. Trabalho, Tecnologia e Organização. São Paulo: Editora Blucher,

Dejours, C. (1992). A loucura do trabalho: Estudo de psicopatologia do trabalho [The madness of work: Study of work psychopathology] (A. I. Paraguay \& L. L. Ferreira, Trans., 5th ed.). São Paulo, SP: Cortez/Oboré.

Ferreira, R. C., Silveira, A. P., Sá, M. A. B., Feres, S. B. L., Souza, J. G. S., \& Martins, A. M. E. B. L. (2015). Transtorno mental e estressores no trabalho entre professores universitários da área da saúde [Mental disorder and stress factors at work among health area professors]. Trabalho, Educação e Saúde, 13(Suppl. 1), 135-155. doi:10.1590/1981-7746-sip00042

Freitas, L. G. (2013). Trabalho vivo. In F. O. Vieira, A. M. Mendes, \& A. R. C. Merlo (Orgs.), Dicionário Crítico de Gestão e Psicodinâmica do trabalho [Critical Dictionary of Management and Work Psychodynamics] (pp. 473-476). Curitiba, PR: Juruá. 
Gonçalves, D. M., Stein, A. T., \& Kapczinski, F. (2008). Avaliação de desempenho do Self-Reporting Questionnaire como instrumento de rastreamento psiquiátrico: Um estudo comparativo com o Structured Clinical Interview for DSM-IV-TR [Performance of the Self-Reporting Questionnaire as a psychiatric screening questionnaire: A comparative study with Structured Clinical Interview for DSM-IV-TR]. Cadernos de Saúde Pública, 24(2), 380-390. doi:10.1590/S0102-311X2008000200017

Hair, J. F., Jr., Black, W. C., Babin, B. J., Anderson, R. E., \& Tatham, R. L. (2009). Análise multivariada de dados [Multivariate data analysis] (A. S. Sant'Anna, Trans., 6th ed.). Porto Alegre, RS: Bookman.

Lima, A. F. T., Coêlho, V. M. S., \& Ceballos, A. G. C. (2017). Violência na escola e transtornos mentais comuns em professores [Violence at school and common mental disorders in teachers]. Revista Portuguesa de Enfermagem de Saúde Mental, (18), 31-36. doi:10.19131/rpesm.0189

Luz, J. G., Pessa, S. L. R., Luz, R. P., \& Schenatto, F. J. A. (2019). Implicações do ambiente, condições e organização do trabalho na saúde do professor: Uma revisão sistemática [Implications of the environment, conditions and organization of work on teacher health: A systematic review]. Ciência \& Saúde Coletiva, 24(12), 4621-4632. doi:10.1590/1413-812320182412.26352017

Marchetti, J. R., Busnello, G. F., \& Kolhs, M. (2016). Agravos à saúde do professor relacionados ao trabalho: Revisão de literatura [Related disorders will the teacher's health work: Literature review]. Revista Uningá Review, 25(3), 71-74. Retrieved from http://revista.uninga.br/ index.php/uningareviews/article/view/1782

Mari, J. J., \& Williams, P. (1986). A validity study of a psychiatric screening questionnaire (SRQ-20) in primary care in the city of São Paulo. The British Journal of Psychiatry, 148(1), 23-26. doi:10.1192/bjp.148.1.23

Mariz, R. S., \& Nunes, C. G. F. (2013). O contexto do trabalho dos professores na educação superior: As mudanças no mundo do trabalho e o trabalho no mundo do trabalho [The context of teachers' work in higher education: Changes in the world of work and work in the world of work]. In L. G. Freitas (Coord.), Prazer e sofrimento no trabalho docente: Pesquisas brasileiras [Pleasure and suffering in teaching work: Brazilian research] (pp. 6789). Curitiba, PR: Juruá.

Medeiros-Costa, M. E., Maciel, R. H., \& Fernandes Gurgel, F. (2018). Transtornos mentais comuns e síndrome de Burnout em agentes penitenciários. Ciencia \& Trabajo, 20(61), 36-41. doi:10.4067/S0718-24492018000100036
Mendes, A. M., \& Ferreira, M. C. (2007). Inventário sobre Trabalho e Risco de Adoecimento- ITRA: Instrumento auxiliar de diagnóstico de indicadores críticos no trabalho [Inventory on Work and Illness Risk - ITRA: Auxiliary instrument for diagnosis of critical indicators at work]. In A. M. Mendes (Eds.), Psicodinâmica do trabalho: Teoria, método e pesquisas [Psychodynamics of work: Theory, method and research] (pp. 111-126). São Paulo, SP: Casa do Psicólogo.

Monteiro, J. K., Brun, L. G., Santos, A. S., Tundis, A. G. O., \& Cardon, S. B. (2019). Distúrbios psiquiátricos menores e fatores associados em professores do ensino privado do Rio Grande do Sul/Brasil [Minor psychiatric disorders and associated factors in teachers of private education in Rio Grande do Sul/Brazil]. Contextos Clínicos, 12(3), 843-862. doi:10.4013/ ctc. 2019.123 .07

Monteiro, J. K., Moraes, R. D., Mendes, A. M., \& Merlo, A. R. C. (2017). Psicodinâmica do trabalho no Brasil: Práticas, avanços e desafios. Curitiba, PR: Juruá.

Neves, M. Y. R., \& Silva, E. S. (2006). A dor e a delícia de ser (estar) professora: Trabalho docente e saúde mental [The pain and the delight of being a teacher: Teaching work and mental health]. Estudos e Pesquisas em Psicologia, 6(1), 63-75. Retrieved from www.revispsi.uerj.br/v6n1/ artigos/PDF/v6n1a06.pdf

Oliveira, V. R., \& Ferreira, J. B. (2015). Clínica da cooperação: Um caminho para a insurgência e a autonomia [Cooperation clinic: A way for the insurgency and the autonomy]. Contextos Clínicos, 8(2), 165-172. doi:10.4013/ctc.2015.82.05

Santos, G. E. O. (2018). Calculadora Amostral: Calculadora Online [Sample Calculator: Online Calculator]. Retrieved from https://praticaclinica.com.br/anexos/ ccolaborativa-calculo-amostral/ccolaborativa-calculoamostral.php

Santos, K. O. B., Araújo, T. M., \& Oliveira, N. F. (2009). Estrutura fatorial e consistência interna do Self-Reporting Questionnaire (SRQ-20) em população urbana [Factor structure and internal consistency of Self-Reporting Questionnaire (SRQ-20) in an urban population]. Cadernos de Saúde Pública, 25(1), 214-222. doi:10.1590/ S0102-311X2009000100023

Tai, K. L., Ng, Y. G., \& Lim, P. Y. (2019). Systematic review on the prevalence of illness and stress and their associated risk factors among educators in Malaysia. PloS One, 14(5), e0217430. doi:10.1371/journal. pone. 0217430 
Van Droogenbroeck, F., \& Spruyt, B. (2015). Do teachers have worse mental health? Review of the existing comparative research and results from the Belgian Health Interview Survey. Teaching and Teacher Education, 51, 88-100. doi:10.1016/j.tate.2015.06.006

Villaverde, D., Unda, S., Escotto, E. A., \& Flores, R. (2019). Personality traits that predict the Burnout syndrome on Mexican teachers. Journal of Educational Psychology Propósitos y Representaciones, 7(3), 57-71.doi:10.20511/ pyr2019.v7n3.346

Luciana Gisele Brun is a PhD in Clinical Psychology from Universidade do Vale do Rio dos Sinos, São Leopoldo-RS, Brazil.

Janine Kieling Monteiro is a Professor at Programa de PósGraduação em Psicologia of Universidade do Vale do Rio dos Sinos, São Leopoldo-RS, Brazil.

Daniel $A b s$ is a Professor of Faculdade de Administração at Universidade Federal do Rio Grande do Sul, Porto AlegreRS, Brazil.

Authors' Contribution:

All authors made substantial contributions to the conception and design of this study, to data analysis and interpretation, and to the manuscript review and approval of the final version. All the authors assume public responsibility for content of the manuscript.

Associate editor:

Luciana Mourão Cerqueira e Silva

Received: Jan. 29, 2020

1st Revision: Jul. 09, 2020

2nd Revision: Oct. 29, 2020

Approved: Nov. 15, 2020

How to cite this article:

Brun, L. G., Monteiro, J. K., \& Abs, D. (2021). Work and common mental disorders in private education teachers: Theoretical model. Paidéia (Ribeirão Preto), 31, e3113. doi:https://doi.org/10.1590/1982-4327e3113 